\title{
EXPERIENCES AND ATTITUDES OF YOUNG PEOPLE AND SENIORS IN RELATION TO PEOPLE WITH INTELLECTUAL DISABILITIES
}

\author{
Zdeňka Kozáková \\ University in Olomouc, Czech Republic
}

\begin{abstract}
The contribution represents the selected summary of the results of research carried out through a questionnaire-based survey and a structured interview, the goal of which was to ascertain the experiences and attitudes of young people and seniorsin relation to mentally impaired individuals and define the spheres to which increased attention should be paid in the future. The examined group comprised 160 respondents. The contribution is introduced by information on the given issue and the definition of the basic terminology in relation to the examined sphere. Subsequently, it presents the methodological outcomes of the research and deals with specific results of the research and discussions. At the end, it summarizes the research conclusions in the context of various points of view of the current state of knowledge in theory and its application in practise.
\end{abstract}

Keywords: mentally impaired individual, mental impairment, attitudes, integration, inclusion, structured interview, questionnaire

\section{Introduction}

People with intellectual disabilities are an integral part of the human society. The attitudes towards these individuals gradually developed and changed depending on the development of the entire human society and the acquisition of new information, experience and knowledge. The historical view of the changes in the attitudes towards mentally impaired individuals may help us understand the source of some current attitudes or prejudices persisting as common and evoking various feelings - ranging from embarrassment, admiration, sympathy to sadness - even today. Before 1989, the medical approach to the mentally impaired, institutional care and separation from the wider public prevailed. Society then had neither much experience with people with disabilities, nor sufficient information. At present, the situation is considerably different and individuals with any type of disability have become an integralpart of society. For this reason, we were interested to know whether these changes and experiences are reflected in the attitudes and the possible prejudices of young people and seniors in relation to the mentally impaired. The principal goal of the research was to ascertain and, subsequently, compare the attitudes of age groups of seniors and young people to mentally impaired individuals. For obtaining the relevant data, we applied a combined method comprising a questionnaire and a structured interview. The examined group was 
comprised of seniors being 60 years old and more and of young people between 20 and 30 years of age.

\section{Basic Terminological Definition}

Mental Retardation: "Mental retardation can be defined as a mental development disorder accompanied by compromised intelligence reflected, in particular, in the compromised cognitive, speech, movement and social abilities with prenatal, perinatal and postnatal aetiology" (Valenta \& Kozáková, 2006, p. $20)$. Mental retardation is usually defined as the inability of an individual to reach the respective level of intellectual development (that is, less than $70 \%$ of the norm) although he/she has been appropriately stimulated in terms of education (Vágnerová, 2004 in Kozáková, 2013). In terms of the intelligence quotient, we can differentiate amongst slight retardation (IQ 50-69), moderate retardation (IQ 35-49), severe retardation (IQ 20-34) and deep retardation (IQ 20 and less) [Kozáková, 2005, p. 22]

Attitude: The Dictionary of Psychology (Hartl \& Hartlová, 2009, p. 442) defines an attitude as a "tendency to react to objects, people, situations and oneself in an established manner. Knowledge, skills and attitudes are acquired during life, in particular, through education and wider social influences such as public opinion, social contacts, and others. They are part of a personality. Attitudes comprise the cognitive component, emotional component, and conative (behavioural) component". The cognitive component represents the level of knowledge of the subject of attitude, the emotional component the emotions in relation to the subject of attitude, and the behavioural component the behaviour towards the subject of attitude.

Prejudice: "Prejudice is a special type of an attitude. The word itself indicates that it is something pre-established, pre-assumed." (Nakonečný, 2009, p. 276) Nakonečný (2009) emphasises that this term has a pejorative meaning since it is usually, but wrongly, tied to undesirable and unjustified opinions, usually towards certain minorities. The fact that these attitudes are strongly emotionally accentuated and, as such, are highly resistant to changes is an essential element of prejudice.

\section{Methodological Research Outcomes}

The principal goal of the research was to ascertain and, subsequently, compare the attitudes of age groups of seniors and young people to mentally impaired individuals.

The partial goal was to ascertain:

- whether seniors and young people encountered mentally impaired individuals;

- whether the experience in encountering mentally impaired individuals influenced the respondents' attitudes towards these individuals; 
- whether seniors and young people had some information on the issue of mental impairment and, if so, from what sources they obtained such information;

- what opinions and attitudes the respondents had with respect to the integration of mentally impaired individuals into society;

- $\quad$ how both age groups pictured a mentally impaired individual.

\section{Applied Methods}

For obtaining the relevant data, we applied a combined method comprising a questionnaire and a structured interview. The questionnaire contained 14 items, of which 13 were closed and 1 was open. Seniors usually made use of the structured interview where the questioner proceeded according to the questionnaire items and recorded the respondent's answers on a score sheet.

\section{Characteristics of the examined sample and the course of research}

The examined group was comprised of seniors being 60 years old and more and of young people between 20 and 30 years of age. Most seniors used the form of a structured interview. Most young people made use of the electronic questionnaire and that on the social networking site Facebook. The other questionnaires were handed over in person and reclaimed after some time.

The research was attended by 160 respondents in total. The specific numbers of male and female respondents are stated in the following Table 1:

Table 1. Respondents by Age and Gender

\begin{tabular}{|l|l|c|c|c|}
\hline \hline \multicolumn{2}{|l|}{ Age Group } & Women & Men & Total \\
\hline \hline 20-30 years & Frequency & 45 & 35 & 80 \\
\hline \hline 60 years and more & Frequency & 53 & 27 & 80 \\
\hline \hline Total & Frequency & 98 & 62 & 160 \\
\hline
\end{tabular}

\section{Research Results Presentation and Discussion}

The intention of the research was to discover and, subsequently, compare the attitudes of seniors and young people towards mentally impaired individuals. At first, we were interested to know whether the age groups of seniors and young people encountered mentally impaired individuals and, if so, whether such experience influenced their attitudes towards these individuals.

Most respondents encountered mentally impaired individuals occasionally (52.50\% of young people and $60 \%$ of seniors). A lower number of respondents did not encounter these individuals $(22.50 \%$ of young people and $18.80 \%$ of seniors). Some respondents knew mentally impaired individuals only from television (10\% of young people and $15 \%$ of seniors), and, conversely, some 
respondents encountered these individuals often $(15 \%$ of young people and $6.20 \%$ of seniors).

Table 2. Encountering Mentally Impaired Individuals

\begin{tabular}{|l|l|c|c|c|c|c|}
\hline \hline Age Group & $\begin{array}{c}\text { No } \\
\text { Encounter }\end{array}$ & $\begin{array}{c}\text { Television } \\
\text { Knowledge }\end{array}$ & $\begin{array}{c}\text { Occasional } \\
\text { Encounter }\end{array}$ & $\begin{array}{c}\text { Frequent } \\
\text { Encounter }\end{array}$ & Total \\
\hline $\begin{array}{l}\mathbf{2 0 - 3 0} \\
\text { years }\end{array}$ & Frequency & 18 & 8 & 42 & 12 & 80 \\
\cline { 2 - 7 } & $\begin{array}{l}\text { Frequency } \\
\text { in } \%\end{array}$ & $22.50 \%$ & $10 \%$ & $52.50 \%$ & $15 \%$ & $\begin{array}{c}100.00 \\
\%\end{array}$ \\
\hline \hline $\begin{array}{l}\mathbf{6 0} \text { years } \\
\text { and more }\end{array}$ & Frequency & 15 & 12 & 48 & 5 & 80 \\
\cline { 2 - 7 } & $\begin{array}{l}\text { Frequency } \\
\text { in } \%\end{array}$ & $18.80 \%$ & $15 \%$ & $60 \%$ & $6.20 \%$ & $\begin{array}{c}100.00 \\
\%\end{array}$ \\
\hline
\end{tabular}

We also examined whether the experience in encountering mentally impaired individuals influenced the respondents' attitudes towards these individuals.

Table 3. Influence of Experience in Encountering Mentally Impaired Individuals

\begin{tabular}{|l|l|c|c|c|}
\hline \hline \multicolumn{2}{|l|}{ Age Group } & Yes & No & Total \\
\hline \hline \multirow{2}{*}{$20-30$ years } & Frequency & 25 & 55 & 80 \\
\cline { 2 - 5 } & Frequency in \% & $31.30 \%$ & $68.70 \%$ & $100.00 \%$ \\
\hline \multirow{2}{*60}{ years and more } & Frequency & 23 & 57 & 80 \\
\cline { 2 - 5 } & Frequency in \% & $28.80 \%$ & $71.20 \%$ & $100.00 \%$ \\
\hline
\end{tabular}

Most respondents (68.70\% of young people and $71.20 \%$ of seniors) agreed that the encounter with mentally impaired individuals did not influence them at all.

The respondents could justify their answers:

- "I am humble and appreciate these people. I treat them with respect." (female, 20-30 years old)

- "I have learnt to treat these people equally." (male, 20-30 years old)

- "You shouldn't laugh at them. You can never know how you will end up." (female, 20-30 years old)

- "They are people like us, but were not as lucky as we were. I appreciate them." (male, 20-30 years old)

- "It can be me who will end up like that." (male, 60 years and more)

- "A nice encounter with health impaired individuals, surpassing of restraints and embarrassment." (female, 60 years and more)

- "I am sorry for them." (female, 60 years and more)

- " A feeling of help and understanding." (female, 60 years and more) 
Furthermore, we focused on the awareness of the age groups regarding mental impairment and through which sources they obtained this information.

Table 4. Awareness of Age Groups of Mental Impairment

\begin{tabular}{|l|l|c|c|c|}
\hline \hline \multicolumn{2}{|l|}{ Age Group } & Yes & No & Total \\
\hline \hline \multirow{2}{*}{$20-30$ years } & Frequency & 70 & 10 & 80 \\
\cline { 2 - 5 } & Frequency in \% & $87.50 \%$ & $12.50 \%$ & $100.00 \%$ \\
\hline \hline \multirow{2}{*60}{ years and more } & Frequency & 73 & 7 & 80 \\
\cline { 2 - 5 } & Frequency in \% & $91.30 \%$ & $8.70 \%$ & $100.00 \%$ \\
\hline
\end{tabular}

It was positive that nearly all respondents stated that they had information on mental impairment ( $87.50 \%$ of young people and $91.30 \%$ of seniors). In this respect, we were interested to know the sources of this information on mental impairment.

Table 5. Sources of Information on Mental Impairment

\begin{tabular}{|l|l||c|c|c|c|c|}
\hline \hline Age Group & $\begin{array}{c}\text { Magazines, } \\
\text { books }\end{array}$ & $\begin{array}{c}\text { Television } \\
\text { radio, } \\
\text { Internet }\end{array}$ & School & $\begin{array}{c}\text { Friends } \\
\text { and } \\
\text { family }\end{array}$ & Total \\
\hline $\begin{array}{l}\mathbf{2 0 - 3 0} \\
\text { years }\end{array}$ & Frequency & 19 & 41 & 28 & 30 & 118 \\
\hline $\begin{array}{l}\mathbf{6 0} \text { years } \\
\text { and more }\end{array}$ & Frequency in \% & $16 \%$ & $35 \%$ & $24 \%$ & $25 \%$ & $100.00 \%$ \\
\cline { 2 - 7 } & Frequency & 33 & 63 & 4 & 7 & 107 \\
\hline
\end{tabular}

The most respondents drew information from television, radio or Internet (35\% of young people and $59 \%$ of seniors). The age group of young people also drew information from school (24\% of respondents) and from family and friends ( $25 \%$ of respondents). Seniors drew information from magazines and books (31\% of respondents).

Moreover we examined the respondents' attitudes towards the integration of mentally impaired individuals into every-day society. As the question was asked, the term 'integration' was explained and the respondents were given the opportunity to express their consent or dissent (Yes/No). The obtained data is stated in the following Table 6:

Table 6. Attitudes to Integration of Mentally Impaired Individuals into Intact Society

\begin{tabular}{|l|l||c|c|c|}
\hline \hline \multicolumn{2}{|l|}{ Age Group } & Yes & No & Total \\
\hline \multirow{2}{*}{$20-30$ years } & Frequency & 66 & 14 & 80 \\
\cline { 2 - 5 } & Frequency in \% & $82.50 \%$ & $17.50 \%$ & $100.00 \%$ \\
\hline \hline \multirow{2}{*}{60 years and more } & Frequency & 73 & 7 & 80 \\
\cline { 2 - 5 } & Frequency in \% & $91.30 \%$ & $8.70 \%$ & $100.00 \%$ \\
\hline
\end{tabular}


The absolute majority of young people $(82.50 \%)$ and seniors $(91.30 \%)$ agreed with the integration of mentally impaired individuals into society. A lower number of respondents dissented (17.50\% of young people and $8.70 \%$ of seniors).

Subsequently, we wanted to discover the opinions of respondents about how mentally impaired individuals were accepted by the majority of society. The obtained data is stated in the following Table 7:

Table 7. Opinion about Acceptance of Mentally Impaired Individuals by Majority Society

\begin{tabular}{|l|l|c|c|c|c|c|}
\hline \hline Age Group & Yes & $\begin{array}{c}\text { Rather } \\
\text { yes }\end{array}$ & $\begin{array}{c}\text { Rather } \\
\text { no }\end{array}$ & No & Total \\
\hline \hline \multirow{2}{*}{$\mathbf{2 0 - 3 0}$ years } & Frequency & 3 & 21 & 41 & 15 & 80 \\
\cline { 2 - 7 } & Frequency in \% & $3.70 \%$ & $26.30 \%$ & $51.30 \%$ & $17.70 \%$ & $100.00 \%$ \\
\hline \hline \multirow{2}{*}{$\begin{array}{c}60 \\
\text { and years }\end{array}$} & Frequency & 8 & 23 & 38 & 11 & 80 \\
\cline { 2 - 7 } & Frequency in $\%$ & $10 \%$ & $28.80 \%$ & $47.70 \%$ & $13.70 \%$ & $100.00 \%$ \\
\hline
\end{tabular}

It was interesting to find out that more than a half of young people $(51.30 \%)$ thought that mentally impaired individuals were not accepted by the majority of society. Nearly a half of the seniors $(47.70 \%)$ thought the same.

Finally, we wanted to know the ideas of respondents regarding a mentally impaired individual. Some of their ideas appeared repeatedly (see Table 8).

Table 8. Respondents' Ideas of a Mentally Impaired Individual

\begin{tabular}{|l|l|c|c|}
\hline Age Group & Answers & Frequency & Frequency in \% \\
\hline 20-30 years & They need supervision, help & 20 & $17.20 \%$ \\
\cline { 2 - 4 } & $\begin{array}{l}\text { Depends on the type of impairment, } \\
\text { various types }\end{array}$ & 39 & $34 \%$ \\
\cline { 2 - 4 } & Speech disorders & 15 & $10.80 \%$ \\
\cline { 2 - 4 } & Different behaviour & 13 & $13 \%$ \\
\cline { 2 - 4 } & Lower IQ & 29 & $25 \%$ \\
\cline { 2 - 4 } & Total & 116 & $100 \%$ \\
\hline \hline \multirow{4}{*}{ 60 years } & Answers & Frequency & Frequency in \% \\
\cline { 2 - 4 } & Speech disorders & 16 & $15 \%$ \\
\cline { 2 - 4 } & Depends on the type of impairment & 19 & $17.90 \%$ \\
\cline { 2 - 4 } & They are noisy & 15 & $14.20 \%$ \\
\cline { 2 - 4 } & Some of them are aggressive & 13 & $12.30 \%$ \\
\cline { 2 - 4 } & Joy & 12 & $19.80 \%$ \\
\cline { 2 - 4 } & Lower IQ & 10 & $9.50 \%$ \\
\cline { 2 - 4 } & They live in their own world & 106 & $100 \%$ \\
\cline { 2 - 4 } & Total & & \\
\hline
\end{tabular}


With respect to the mentally impaired, both age groups consensually stated that it depends on the type of impairment. Many answers stated that mentally impaired people have lower $I Q$ and speech disorders. The respondents-young people (between 20 and 30 years of age) also stated the need for supervision and help. The respondents-seniors (60 years of age and more) stated, alongside the foregoing, that mentally impaired people are noisy, aggressive, express joy and live in their own world.

The following text states some of the respondents' answers:

- "It's an individual who is sincere and has a soul of a child. He/she takes things as they are. He/she can be happy and satisfied." (female, 20-30 years old)

- "He/she has difficulties in communication, is slow and thinks solely." (male, 20-30 years old)

- "It is an individual who is not able to live a full-fledged life." (female, 20-30 years old)

- "It is an individual who thinks too much about his/her acts, what he/she is doing, why and what are the conclusions, consequences and results of such action." (male, 20-30 years old)

- "These people are nice, like playing. They are like children. Although they are impaired, I respect them." (male, 20-30 years old)

- $\quad$ "They are nice most of the time, but sometimes aggressive, act like children. Some of them are able to live an independent life." (female, 20-30 years)

- $\quad$ "An independent individual...during the day, he/she spends time in the care centre and goes home (hostel, independent accommodation) in the evening. Most mentally impaired individuals spend their time in sanatoriums with permanent supervision." (female, 20-30 years old)

- $\quad$ "It depends on the degree of mental impairment. Some are able to function independently, with occasional supervision, and others cannot do without constant help." (male, 20-30 years)

- "It depends on the impairment. They have difficulties in expressing themselves, their IQ is lower, more things take them longer and they are slow." (female, 20-30 years)

- "I know mentally impaired individuals who attend a protected workshop every morning. These are self-sufficient, decent, greet everyone with a smile and are nice." (female, 60 and more years old)

- "It is an ill person dependent on healthy people." (female, 60 and more years old)

- "He/she expresses himself/herself badly, is sincere and nice." (female, 60 and more years old)

- $\quad$ "He/she lives in a different world. I have an autistic in my family and know what it is like." (female, 60 and more years old) 
- "They forget a lot, everything must be repeated. They speak badly." (male, 60 and more years)

- "They are cheerful, like having fun. They speak a bit badly, but otherwise they're normal like us." (female, 60 and more years old)

- $\quad$ They are able to behave normally, do not speak much and prefer listening to others." (male, 60 and more years old)

- He/she often cries, is noisy, but does not realize it. He/she is able to produce something (ceramics), is skilful. Some of them are decent." (male, 60 and more years old)

- $\quad$ "They are nice, cheerful. Some of them are rather introverted, some have problems articulating." (female, 60 and more years old)

We can see that the concepts regarding thementally impaired are manifold and diverse in both age groups and reflect on the personal experience and information of respondents.

\section{Research Results and Discussion}

There are not any significant differences in the sphere of encountering mentally impaired people. Both groups meet or not meet mentally impaired individuals with quite the same frequency. The respondent's place of living rather than his/her age is decisive, that is, whether he/she lives in the country, in the city or in a house for seniors, whether, for example, there is a house for health impaired individuals, a care centre, etc. in the vicinity to where the respondent lives. If there is a facility for mentally impaired individuals close to where the respondent lives, a higher level of experience and higher frequency of encountering these individuals are probable. Compared to this, a respondent living, for example, in a small village far from any such a facility, he/she may have less information and experience in this sphere.

Both groups of respondents consensually stated that they encountered mentally impaired individuals quite often, seeing them in the streets, in shops and cinemas and at the doctor's. Moreover, both groups of respondents also agreed that their encountering mentally impaired individuals did not influence their attitudes and opinions much. Encountering these individuals was a common matter for them. They perceived these individuals as anyone else and were not taken aback by their possible specific exhibitions.

We were also interested to know the level of the respondents' awareness of mental impairment and its causes, exhibitions and consequences. Both age groups obtain information on mental impairment from various sources, but mostly from the television, radio or Internet. Seniors also make use of information in magazines and books. Today's society offers many possibilities to obtain information on various types of impairment, the facilities for these people, etc. It rather depends on the abilities, opportunities and interests. 
The age group of young people often uses modern technologies, mobile phones and the Internet. This way, they can easily get to plenty of information that is not available on the television or in magazines. However, it is also necessary to realize the possible risk of inaccuracy or distortion of the presented information. The attitudes of respondents between 20 and 30 years of age are also influenced by various institutions, in particular, education, and by various groups, such as family, friends, interest groupings, etc. A high number of young people study at university level familiarise themselves with basic information on individuals with disabilities within their various study fields.

We have obtained a lot of data and information from which it ensued that there were no considerable differences in the attitudes of the examined groups in terms of the respondents' age.

\section{Conclusion}

It can be stated that the research results did not confirm any significant differences in the attitudes of young people and seniors towards mentally impaired individuals.

The question relating to consent towards mentally impaired people being integrated was answered positively by most respondents from both categories. However, most of them also think that mentally impaired individuals are actually not accepted by society and are not involved much in social life activities, which should be improved.

Inclusion is a modern approach to integrating individuals with disabilities into society. The inclusive approach lies in the persuasion that all people are equal in their dignity and rights and enrich society. Inclusion can be understood as an approach of society which accepts divergence of all its members and within which it is absolutely common to be different. Thus, within the inclusive approach, individuals with disabilities are engaged in common life and in all common activities, similar to people without any disabilities.

\section{References}

Hartl, P., Hartlová, H. (2000). Psychologický slovnik. Praha: Portál, p. 774.

Kozáková, Z. (2005). Psychopedie. Olomouc: Univerzita Palackého v Olomouci, p. 74.

Kozáková, Z. (2013). Special Education of Persons with Mental Disabilities. Olomouc: Univerzita Palackého v Olomouci, p. 117.

Nakonečný , M. (2009). Sociální psychologie. Praha: Academia, p. 498.

Vágnerová, M. (2004). Psychopatologie pro pomáhajicí profese. Praha: Portál, p. 870.

Valenta, M., Kozáková, Z. (2006). Psychopedie 1 pro výchovné pracovníky. Olomouc: Univerzita Palackého, p. 61. 